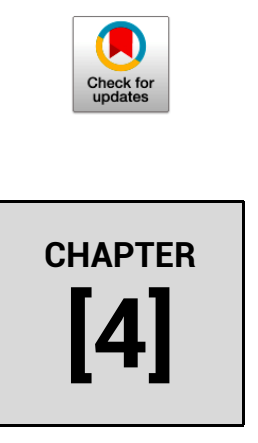

In: Environmental Degradation: Causes and Remediation Strategies

DOI: 10.26832/aesa-2020-edcrs-04

\title{
A review on general characteristics, classification and degradation of river systems
}

\section{Vishal Kamboj, Nitin Kamboj ${ }^{*}$ and Amit Kumar Sharma}

Department of Zoology and Environmental Science,

Gurukula Kangri Vishwavidyalaya, Haridwar-249404 (Uttarakhand), India

Rivers play an important role in the life of human beings. Most of the ancient cities are situated near the river systems and peoples were dependent on it for their livelihood needs, transportation, and raw material for construction, drinking and irrigation purpose. The degradation of the river system is based on river bed material and discharge of environmental pollution such as wastewater, agricultural runoff, and also tourism activities. Besides this, discharge of wastewater, tourism activity, and agricultural runoff into the river causes the eutrophication condition due to the discharge of nutrients in excess amount. The mining activity also affects the floodplain area and riparian zone of the river which causes the flood condition in the river. The mining activities led to change the channel morphology characteristic, increased the progressive degradation in upstream and downstream stretch and also it changes the substrate structure of the river. These activities directly affect the aquatic biodiversity and river regime. For preventing the river system some natural material and man-made methods such as plantation of vegetation and trees, training the river bank with stone, rocks. Therefore, this chapter emphasizes how the rivers system is classified on the basis of sources, geomorphological characteristics, river age, stream order, biotic zone classification and whitewater classification methods and also discuss the degradation of the river system by the river bed material and environmental pollution activities. 


\section{Introduction}

Rivers, a vital part of the freshwater ecosystem usually known as a flow of natural watercourse that flows towards the sea, ocean and other areas. Rivers are the strip connecting the terrestrial environment with the ocean realm (Padmalal and Maya, 2014). Rivers are the prominent geological agent who transfers the materials from terrestrial to the ocean by erosion process. The flowing water collected in the river is a part of the hydrological cycle through these processes such as precipitation, surface runoff, melting of the glacier, groundwater, and natural springs. Flowing water is the main agent of the erosion process, creation of channel path and physical habitat in a river system (FAO 1998; Padmalal and Maya 2014). Flowing water create, destroy and re-creates the landforms, channel pattern, and habitat of the biotic community. In the entire world, most of the cities, villages are situated nearby the rivers for their daily needs like fresh water for drinking, irrigation purpose, food, transportation, and other activities.

Therefore, this chapter represents how the rivers system is classified on the basis of sources, geomorphological characteristics, river age, stream order, biotic zone classification and Whitewater classification methods and also discuss the degradation of the river system by the river bed material and environmental pollution activities.

\section{Classification of river systems}

Generally, the rivers are classified on the basis of the following characteristics (Figure 1):

\section{On the basis of Source}

Sources refer to the beginning point or path of the river and also called a course. The ending point of the river called mouths. The river is divided into two-part on the basis of water flow such as upstream (direction of flowing water towards the source) and downstream (direction towards the mouth of the river). The rivers are classified on the basis of source divided into three types.

Mountain River: The mountain rivers refer to those rivers which start from the mountains also called as glacier-fed rivers and Perennial river. In the northern part of India, most of the rivers start from the mountains. For example, the Ganga river started from Gangotri Glaciers, Yamuna river started from Yamunotri glacier, Alaknanda river started from the Satopanth glacier.

Subsurface streams: The subsurface streams refer to that river that flows underground in caves, glaciers and ice sheets. These rivers mostly found in the limestone geological formation region.

Seasonal or ephemeral rivers: Seasonal or Ephemeral rivers depending on the precipitation/ rainfall of that area. In this type of river, water flows occasionally in monsoon months. In other months, these rivers show a dry flow. In most of the Indian cities, these types of the river called 


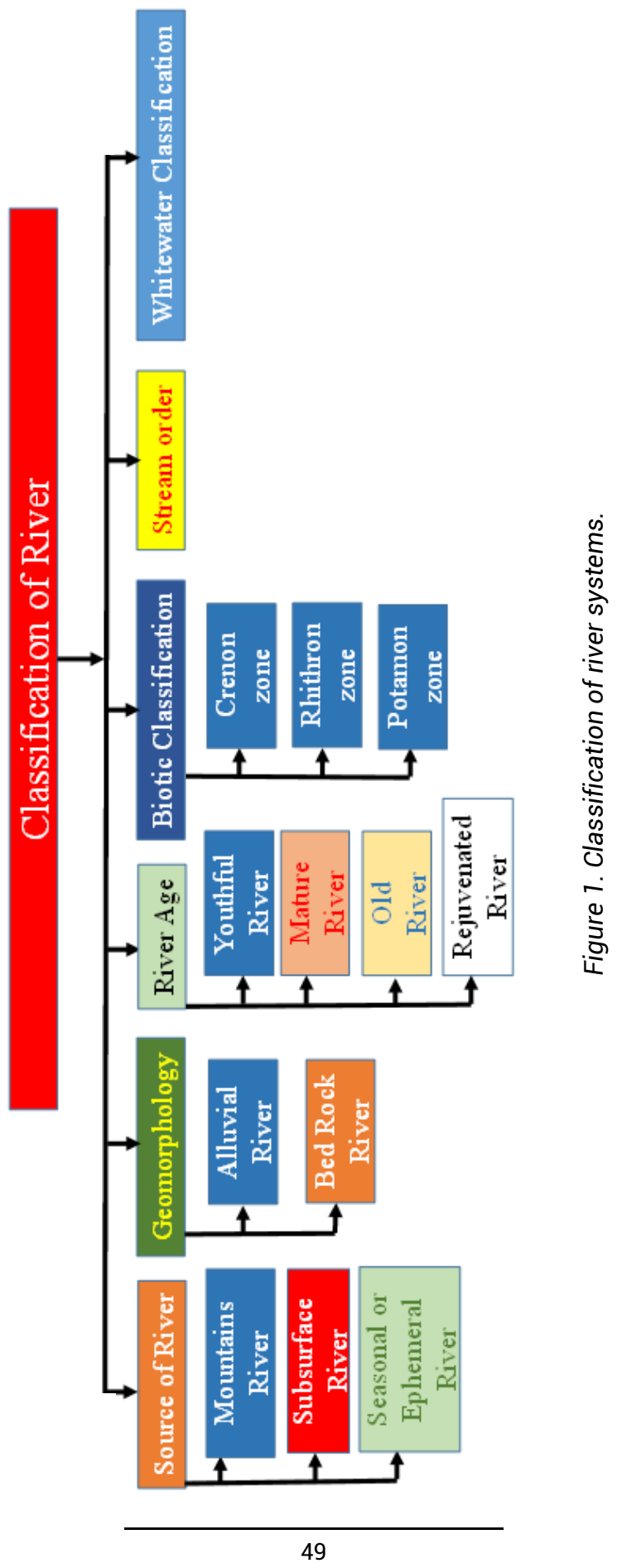


Rao. For example, in the Haridwar district of Uttarakhand, many seasonal rivers are present namely Sukh Rao, Ranipur Rao, Chilla Rao, etc.

\section{On the basis of geomorphology}

In the entire world, rivers play an important role to transfer raw materials like sand, gravel, boulder and other debris loads from one point to another point (Kamboj et al., 2017). The bed of the river is the combination of geomorphology materials like boulder, stone, sand, and silt. These types of the river maintain their watercourse by erosion. The rivers classified as on the basis of geomorphology characteristics as follows:

\section{Alluvial rivers}

The alluvial rivers refer on the basis of channel pattern, floodplain areas that are created, destroy and recreate by weakly consolidated sediments. Channel pattern refers to the path of the watercourse and floodplain area refers to the nearby area of the river which consists of sediments. The alluvial river also classified into five major types on the basis of channel pattern using calculate the sinuosity index (straight channel, sinuous channel, meandering channel) and on the geomorphological characteristics (braided channel and Anabranching channel) of the river (Leopold et al., 1964; Miall, 1985).

Sinuosity Index: The sinuosity index is a method to know the pattern of the channel watercourse. The sinuosity index refers to the length of the channel water course divided by the straight length of the river from one point to other point in Table 1 and Figure 2. The formula for calculating the Sinuosity index is given below:

Sinuosity index $(\mathrm{SI})=\frac{\text { Length of water course }(\mathrm{Lw})}{\text { Straight length of the river }(\mathrm{SLw})}$

On the basis of the sinuosity index alluvial channel divided into three types such as straight channel, sinuous channel, and meandering channel.

a) Straight channel: The straight channel refers to when the sinuosity index value is less than 1.05. In the natural river system, the straight channel found only a short length at the upstream and source point of the river.

b) Sinuous channel: The sinuous channel is when the sinuosity index value lies between 1.05 to 1.50. Most of the alluvial rivers show the sinuous channel chrematistics.

c) Meandering channel: The meandering channel occurs when the value of the sinuosity index is greater than the 1.50. These types of channels found in almost the rivers. The meandering channel is consisting of riffles, pools and provides the habitat for aquatic organisms.

On the basis of geomorphological characters, alluvial rivers divided into two types such as Braided channel and Anabranching River Channel. 


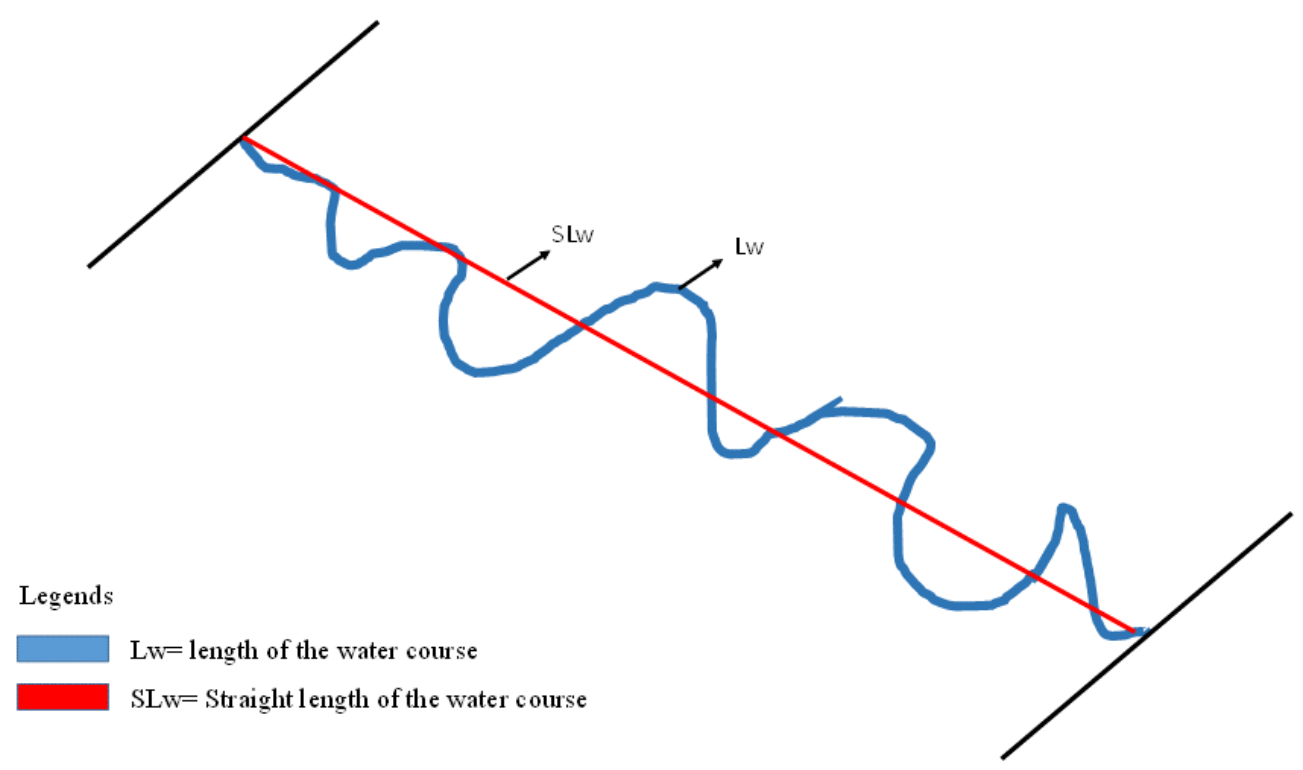

Figure 2. Method of calculating the sinuosity index.

Table 1. Types of the alluvial river on the basis of the sinuosity index.

\begin{tabular}{ll}
\hline Types of river & Sinuosity index \\
\hline Straight Channel & $>1.05$ \\
Sinuous Channel & 1.05 to 1.50 \\
Meandering Channel & $<1.50$ \\
\hline
\end{tabular}

a) Braided river channel: The braided channel defined as the separation of the main channel in many channels due to the permanent and temporary bars, islands. The condition of the braided channel is generally shown in most of the river system (Figures 3 and 4). The formation of a braided channel in a rivers system is due to the high sediment load, high water flow, high meandering pattern, weak bank and steeper slope (Schumm and Kahn, 1972).

b) Anabranching river channel: The anabranching channel mostly looks like the braided river channel. It consists of a number of the channel which is separated by the vegetation, alluvial island in the active channel not in the floodplain area (Nanson and Knighton, 1996). The formation of these types of rivers due to the low and high water flow and banks that are stable sediments. The anabranching river channel is divided into six classes on the basis of stream energy (flow of water), size of sediments, and morphological characteristics (Table 2).

\section{Bedrock rivers}

The formation of bedrock rivers is occurring where the flow of water passes through the new 


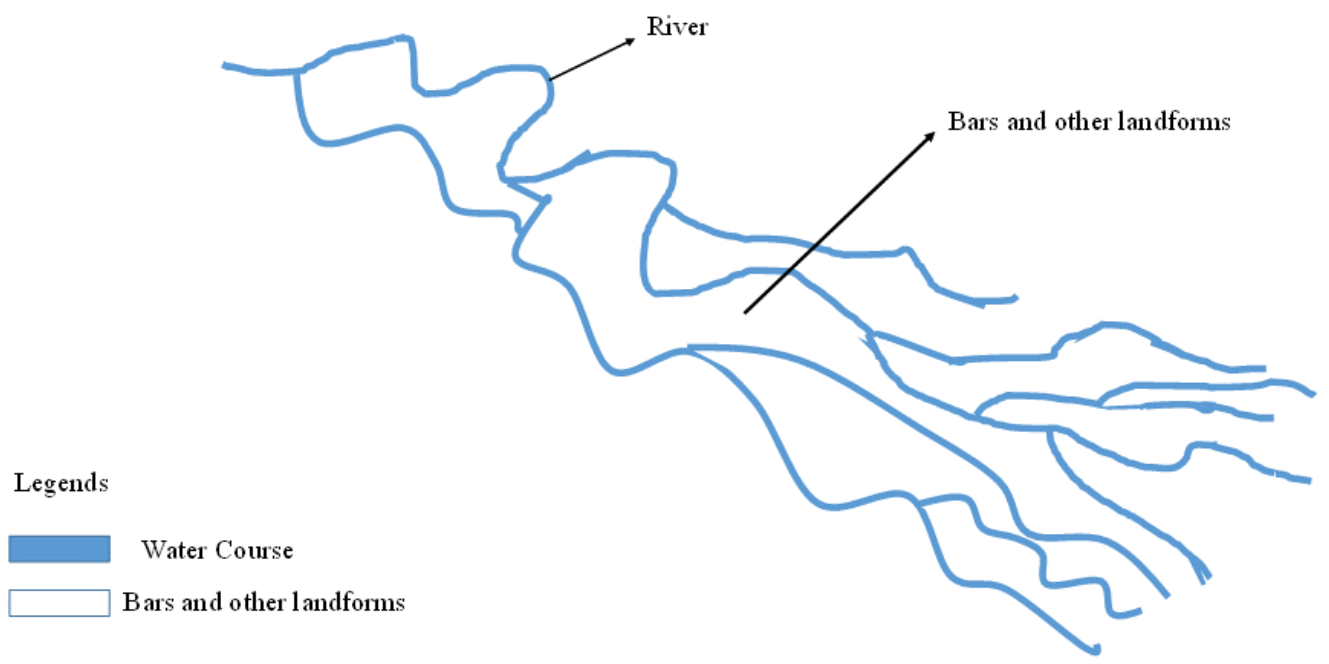

Figure 3. Sketch map showing the braided channel condition.

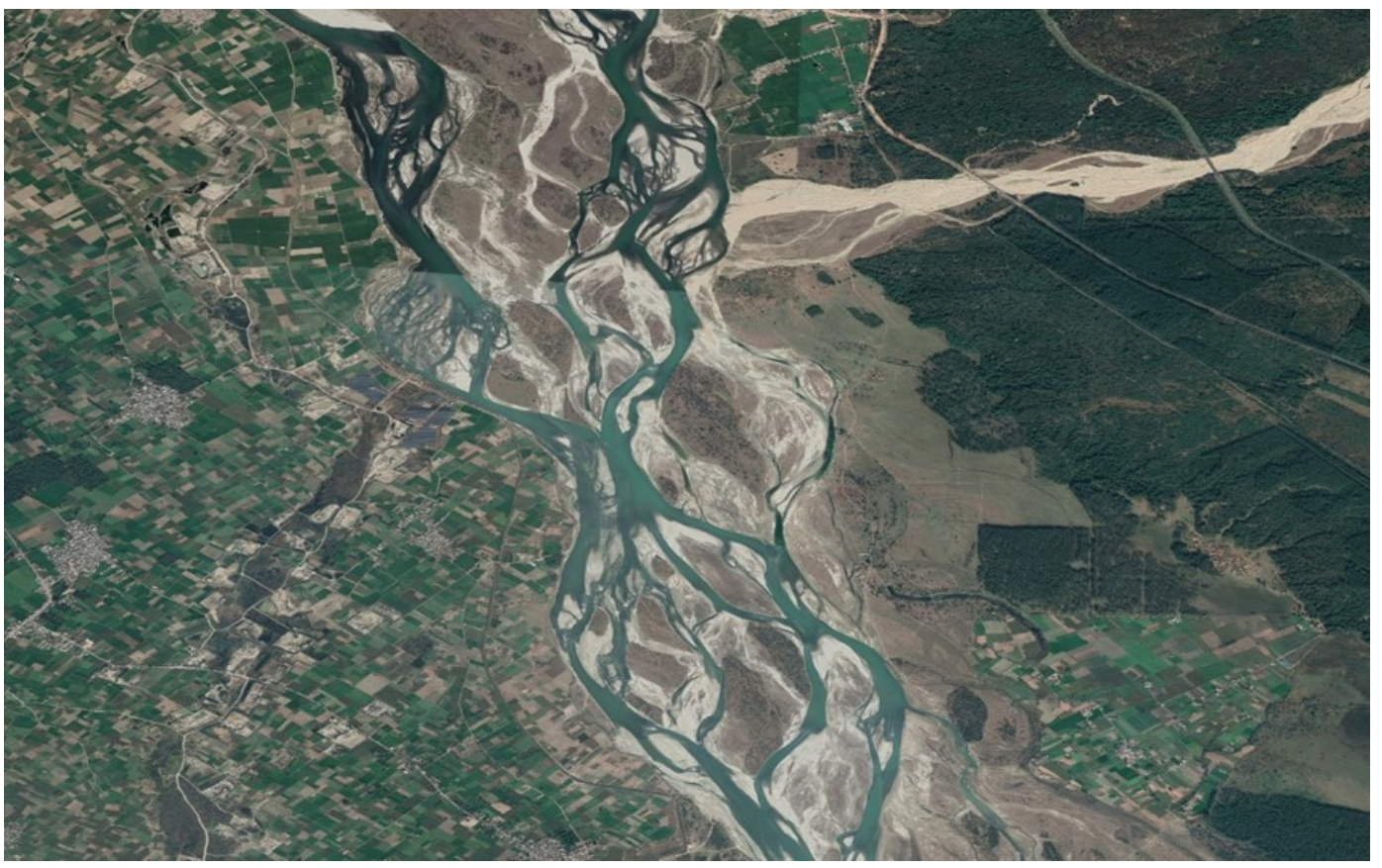

Figure 4. A satellite view of the Ganga river at Haridwar showing the braided channel condition. 
Table 2. Type and condition of the anabranching river channel.

\begin{tabular}{|c|c|c|}
\hline Type & Condition & Reference \\
\hline Type 1 & Lower energy, cohesive sediments, low width and depth & Nanson and \\
\hline Type 2 & Lower energy, sand dominated, island forming rivers & Knighton \\
\hline Type 3 & $\begin{array}{l}\text { Lower energy, active meandering river, a mixed load of sedi- } \\
\text { ments }\end{array}$ & 1996). \\
\hline Type 4 & $\begin{array}{l}\text { Higher energy, sand dominated, channel dividing ridges, long } \\
\text { and parallel ridge forming rivers }\end{array}$ & \\
\hline Type 5 & $\begin{array}{l}\text { Higher energy, gravel dominated, active system that lines the } \\
\text { braiding and meandering in mountains part }\end{array}$ & \\
\hline Type 6 & $\begin{array}{l}\text { Higher energy, gravel dominated, stable system, steep basin, } \\
\text { and non-migrating channels }\end{array}$ & \\
\hline
\end{tabular}

level of sediments where bedrock is below. These types of rivers commonly found in upland and mountainous rivers where the earth's surface is shifting upwards. The formation of these types of rivers is due to the alluvial in nature, weakly sediments, and banks and the high flow of water. The best example of a bedrock river is the Colorado river (United States).

\section{On the basis of river age}

The study of river age also known as the chronological classification of rivers on the basis of study about the changing of river path and pattern of erosion. On the basis of a cycle of erosion developed by William Morris Davis, the rivers are classified into four types such as Mature rivers, Old rivers, Rejuvenated rivers, and Young channel. This theory is rejected by the geomorphologist because it does not produce a testable hypothesis and this theory is nonscientific (Castree, 2006). On the basis of Davis theory, the rivers are classified as:

Youthful river: According to the Davis theory, these types of rivers are steep gradient as well as they have few tributaries along with a rapid flow. The channel of these types of the river is deeper rather than wider. The examples of the youthful rivers are Brazos, Ebro and Trinity rivers.

Mature river: The formation of these types of rivers with a gradient that is not steep, in which flow of water is slower and also fed by many tributaries having more discharge as a comparison to the youth river. The channel of these rivers is eroding wider as opposed to deeper. The examples of mature rivers are Thames, Ohio, Danube and Mississippi rivers.

Old river: These types of the river are classified on the basis of their floodplain areas along with low gradient and low erosive energy. The examples of the old rivers are lower Ganges, Indus, lower Nile, and Yellow rivers.

Rejuvenated river: These types of the river have various gradient which is raised by the tectonic movement. The example of the rejuvenated river in Colorado and the Rio Grande rivers.

\section{On the basis of biotic zones}

Rivers are the example of a lotic ecosystem. It refers to the flowing water in a landscape include 
with the biotic community such as producers (plankton community), consumer (fishes) and decomposers (micro-organisms) as well as abiotic factors (Alexander and Fairbridge, 1999; Angelier, 2003).

In a river system, the zones are divided by the river bed gradient, velocity of the current and other abiotic factors such as temperature. Illies and Botosaneanu (1963) and Hawks (1975) divided the rivers into three primary zones according to the presence of abiotic and biotic factors as seen in Figure 5:

Crenon zone: The crenon zone is that area that is near the source of the river or where the river gets it to start. The crenon zone divided into two zones namely the eucrenon zone and hypocrenon zone. The eucrenon zone is the spring zone and hypocrenon zone is the headstream zone. In these areas, the temperature of the water, oxygen level and flow of water are low.

Rhithron zone: A rhithron zone is the upstream area of a river characterized by the presence of following conditions/factors such as steep gradient, narrow and shallow rapids, and riffles, deeper, flatter pools. In this zone, the flow of current is higher in riffles rather than the pools. In riffles, vegetation is attached with boulder, stone, rock. In pools, vegetation is attached to the fine material and some other rotting vegetation. In the rhithron zone, the temperature is low and the dissolved oxygen is high. In the rhithron zone, the main biotic community is consisting of plankton, periphyton, nekton and a variety of benthos. The rhithron zone absents in the tropical river and found relatively lengthy in temperate rivers.

Potamon zone: A potamon zone is the downstream area of a river with flat gradient, lower speed, lower oxygen content, the temperature of the water is warmer than the rhithron zone and the river bed is sandy. In the potamon zone, the presence of habitats is depending on the meanders of the channel as well as different the main channel and floodplain areas. The potamon zone is the more complex and differs environmentally from the rhithron zone based on the following aspects such as geomorphology of the channel, submerged vegetation, quality of water, biotic community and bacterial density is high.

\section{Classification on the basis of stream order}

Stream order is a method based on the number that shows how a number of tributaries link to a stream network. Most of the rivers are first order and second order rivers. For example, the Ganga river is the second-order stream and the Amazon river is the twelfth river. The concept of stream order method proposed by two scientists namely Strahler and Shreve.

Strahler stream order: The Strahler describes the stream order is the linking of tributaries in a stream network. according to this method, all the rivers start with the first order. When two first-order tributaries are linked together with a point after this the stream order is two. If the two order stream linked with another two order stream than it creates the third-order stream (Figure 5 and 6). This is the most common method of stream order (Tarboton, 1991). 


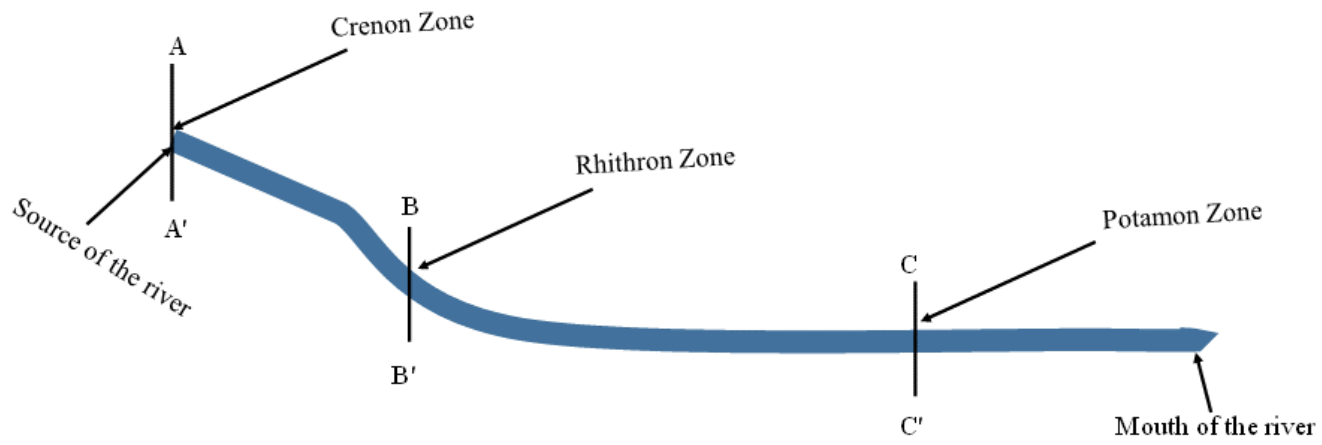

Legends

River

Figure 5. Diagrammatic representation of the longitudinal profile of the river course showing biotic zones.

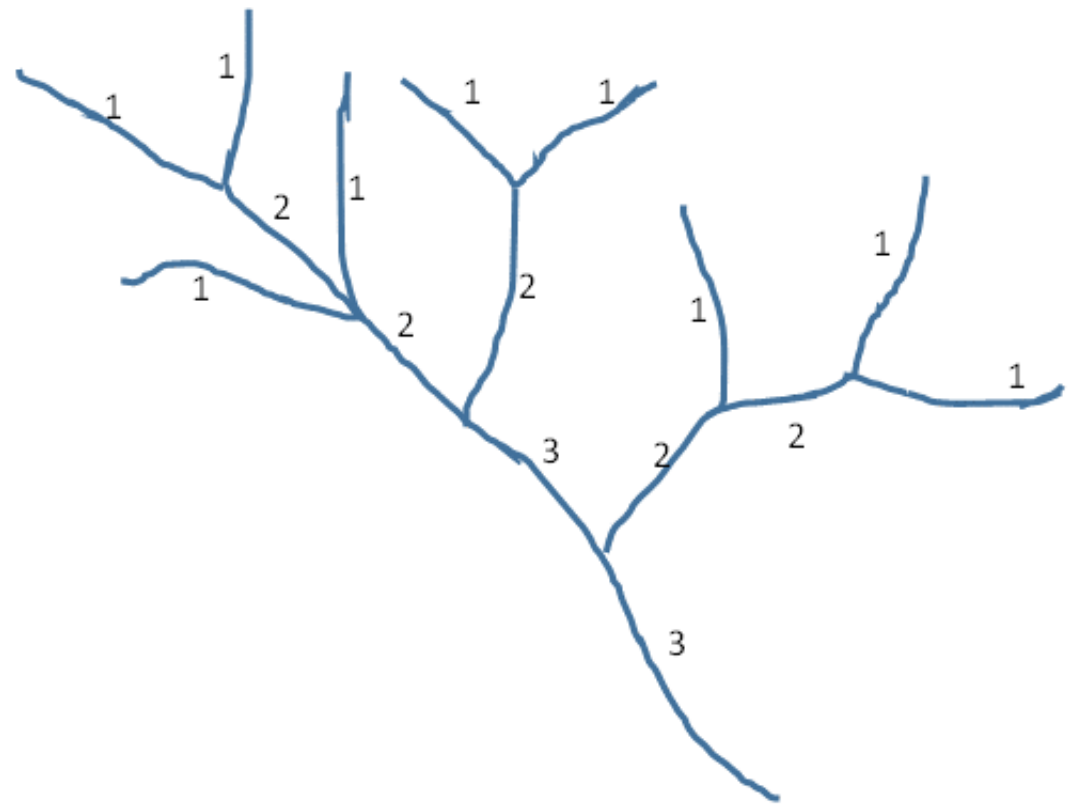

Figure 6. Diagrammatic map of Strahler stream order. 


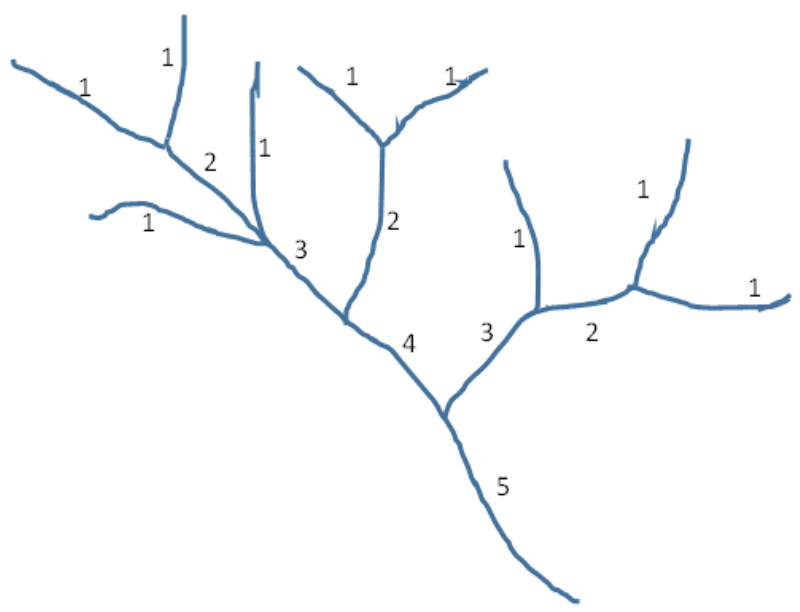

Figure 7. Diagrammatic map of Shreve stream order.

Shreve stream order: According to the Shreve stream order, all links in the network are accounts. In this method, all the orders are additive and all link which starts with the source assigned as the first order. The orders are additive sometimes referred to as magnitudes instead of orders and show the number of upstream links (Figure 7). The first-order stream is linked with the secondorder stream than it creates third link stream and second-order stream linked with the third-order stream than it creates fourth-order streams and so on (Tarboton, 1991).

\section{On the basis of whitewater classification}

Whitewater classification is the classification method based on the navigation challenges, recreational activities and healthy ecosystem of a freshwater river (Table 3). The International scale of river difficulty divided the whitewater classification into six classes on the basis of some condition. The class I is the easiest and Class VI is the hardest class (Walbridge and Singleton, 2005).

\section{Degradation of the river system}

The term degradation refers to the erosion of the earth's surface due to the natural and anthropogenic activity. In a river system, two terms are used aggradation and degradation. Aggradation terms refer to the increase in land elevation due to the deposition of sediments in a river system, it occurs on that area where the supply of sediment is higher than the transport of other material (Gibling, 2005). Degradation is differing from the aggradation process, it refers to 
Table 3. Classes of Whitewater classification (Source: ISRD, 2005).

\begin{tabular}{|c|c|c|}
\hline Class name & $\begin{array}{l}\text { Water flow/Swimming } \\
\text { condition for peddlers }\end{array}$ & Conditions according to rapids and waves \\
\hline Class I & Easy & Fast flow, small waves, easy to swim \\
\hline Class II & Novice & Rivers are wide, waves are medium-sized, \\
\hline Class III & Intermediate & $\begin{array}{l}\text { Waves are irregular and intermediate the difficulty } \\
\text { level }\end{array}$ \\
\hline Class IV & Advanced & $\begin{array}{l}\text { Rapids are intense and powerful but predictable, } \\
\text { unavoidable waves, a good skill for swimming, risk of } \\
\text { a swimmer is moderate to high }\end{array}$ \\
\hline Class V & Expert & $\begin{array}{l}\text { Rapids are extremely long, violent and obstructed; } \\
\text { waves are large, unavoidable and hole or steep; } \\
\text { scouting is recommended but swimming is dangerous, } \\
\text { a good skill for swimming }\end{array}$ \\
\hline Class VI & $\begin{array}{l}\text { Extreme and } \\
\text { exploratory rapids }\end{array}$ & $\begin{array}{l}\text { Rapids/ run in this class are rarely attempted, very } \\
\text { difficult and dangerous, swimming is done for expert } \\
\text { only with good equipment }\end{array}$ \\
\hline
\end{tabular}

the lowering of the stream bed and floodplain area through an erosional process (Galay, 1983). Degradation is a vital part of channel network which maintain the sediments loads either than other materials loads by bedrocks erosion process.

\section{Degradation types of a river system}

On the basis of progressive degradation, it may be divided into two types i.e. upstream progressive degradation and downstream progressive degradation (Figure 8).

Upstream progressive degradation: The degradation of the upstream part of a river is generally the result of the three primary causes such as lowering of base level due to the increase in slope, decreasing the river length and removing the control point. Each of the primary causes of the upstream part is discussed on the basis of the type of river change and engineering work on that part.

a) Lowering of base-level: Lowering of base level in an upstream part of the river is happening due to some condition and works such as drop-in lake level, drop-in level of the main river, mining of bed material. In the downstream base level of a river, it may be a lake, a reservoir, and sea. The main reason for the drop in lake level is the steeping of river slope and higher velocity (Galay, 1983). The drop-in level of the main river regularly causes the degradation problem in the main river and its tributaries. The main cause of the lowering of base level in the upstream area is due to mining of river bed materials. The excavation of the river bed increases the slope, and degrade the natural ecosystem of the river (Kondolf, 1997; Kamboj et al., 2017).

b) Decrease in river length: In the upstream part, the main reason for the decrease in river length is the cutoff of the river, channelization, and regulation of river and horizontal shift of base level. 


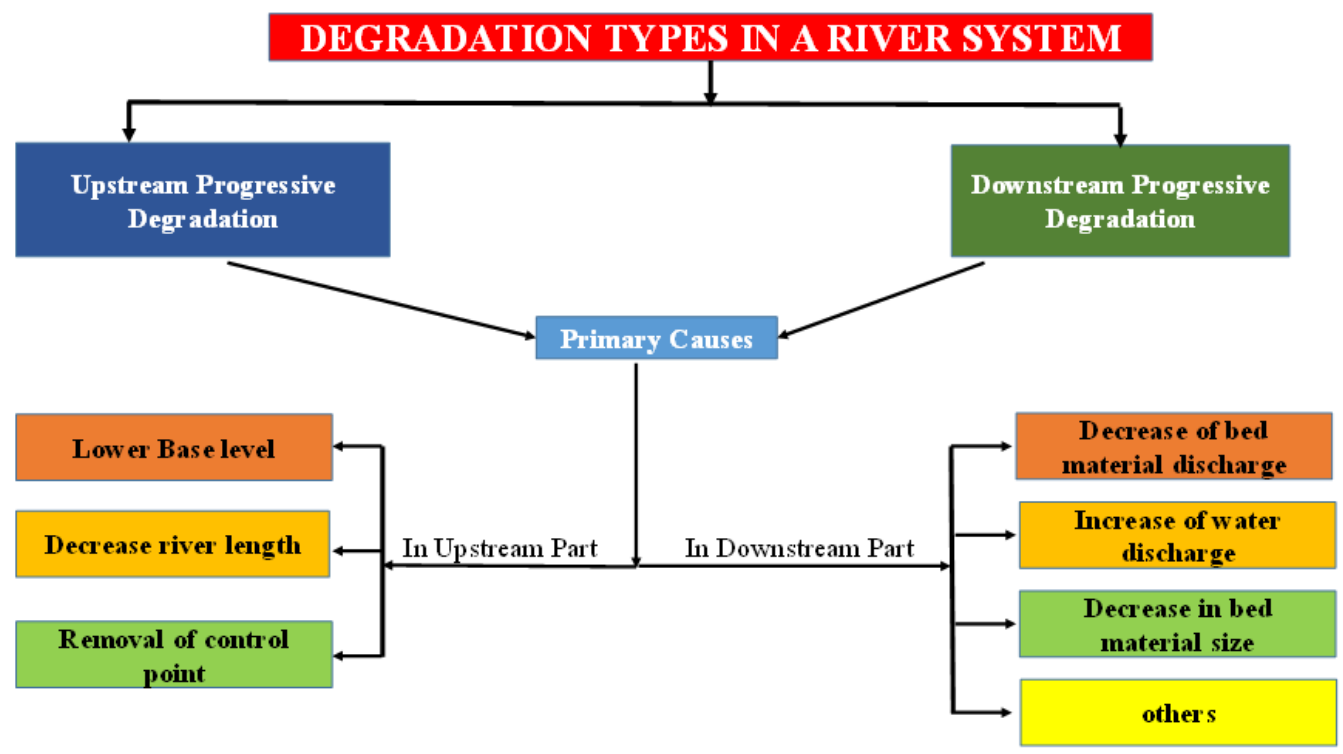

Figure 8. Types of river system degradation.

The cutoff of the river can be natural and man-made that leads to a decrease in river length by increasing the slope. The long series of cutoff separate the river into channelization. The channelization involves the uniform width and depth. Another primary cause of the decrease in river length is the horizontal shifting of the base level. It is the common situation on a river that is the removal of the alluvial part due to the erosion and high flow.

c) Removing the central point: Removing of the central point is done in two ways: 1) natural erosion 2) removal of dam or weir. A central point or Knickpoint usually causes a sudden drop in water level. The removal of the central point shows unstable conditions in the river and it stable itself by the upstream progressing degradation process. The other factor is the removal of the dam or weirs. In this process, the suddenly remove of the sediments from the reservoir cause the upstream degradation.

Downstream progressing degradation: The degradation of the river in the downstream part due to changes variables such as discharge, bed material size, and discharge. There are some factors such as the construction of a high and low dam, mining of bed materials, diversion of bed material, storage of bed material and change in land use show the decrease of bed material discharge downstream. Downstream part sometimes, the flow of water discharge is increase due to the diversion and rare floods. The downstream part of the river is the deposition zone in which the bed material size is less and mostly alluvial in nature. Due to this, the erosion rate in this area is increased. Some other factors such as emerging the river from lake, thawing the subsurface 
permafrost also show the degradation progressing in the downstream part of the river.

Environmental pollution: The river system is also degrading by environmental pollution such as mining, discharge of wastewater (sewage and effluent), tourism activity, agricultural runoff and many other activities (Warner, 1991). These activities affect the quality of water and also biota of the river system. Due to the mining activity, the turbidity level is increased and affects the other biological factors (Kamboj and Kamboj, 2019a). The mining activity also affects the floodplain area and riparian zone of the river which causes the flood condition in the river (Kamboj and Kamboj, 2019b). Discharge of wastewater, tourism activity, and agricultural runoff into the river causes the eutrophication condition due to the discharge of nutrients in excess amount (Kamboj et al., 2016; Kumar et al., 2018). These activities directly affect the aquatic biodiversity and river regime.

\section{Mitigation strategies of river degradation}

The erosion process is normally occurring in all type of aquatic system may be due to the high flow of water, steep slope, alluvial nature of river and river bed material, heavy sediments loads, river bed mining activities, cutoff nature of the river, construction of dams and other process also (Kondolf, 1997; Kamboj, 2013). In this part, we discussed some methods to protect the river basin from the erosion process. The methods or technique used for controlling the erosion are as follows

Natural material methods: In this method, we used natural materials and techniques to control the erosion process near the river bank. Some natural materials such as Coir Geotextile (use of coconut fibers), Brush mattress (bundles of sticks and other materials), Rootwad composites (combination of interlocking of tree roots and other vegetation), Tree revetment (small trees, shrubs, herbs, and grasses) are laid near the stream bank for protecting the river bank (Kamboj, 2012). The natural materials used to protect the riverbank are biodegradable and also it cannot affect aquatic organisms. These methods are not done in that area where the rate of erosion is higher.

Man-made/engineering methods: There are some methods that are based on natural and man-made materials for preventing the river bank. Some example of this methods are Gabions (create the big box type structure with combined use of stones and manufactured metal wires in the most eroded part of the river), Riprap (combine the rocks and other materials in a large area, this method is most expansive), Windrows and trenches (pilling of erosion-resistant material where the bank eroded), Sacks or blocks (filled with material, block the drainage and vegetation growth, used only in flooding condition), soil-cement (construction of the cement wall on the basis of wave condition i.e. if flow of wave is higher than cement wall is made up in stair-step 
pattern and if flow of wave is lesser than the cement walls is made up in parallel to the slope at the river bank (Hansen, 2000; Holste, 2013). This method is not used in the steep slope.

\section{Conclusion}

The present chapter discusses the general feature, characteristics, classification, degradation and preventing measures of a river system. The river system classified on the six major types such as source, geomorphological characteristics, stream order, biotic zone classification, river age, and whitewater classification. The river system is affected by some major conditions such as the flow of water body, slope, width, depth, type of biota, bank condition, sediment material, and floodplain area. The degradation of the river system is based on river bed material and discharge of environmental pollution such as wastewater, agricultural runoff, and also tourism activities. For preventing the river system some natural material and man-made methods such as plantation of vegetation and trees, training the river bank with stone, rocks.

\section{Recommendations}

- Nowadays, through satellite mapping and by the use of remote sensing and geographical information system (RS\& GIS) technique, so that we could identify the proper location of the erosion part of the river system should be done.

- By this technique, calculation of the erosion rate, sediment transport and how much channel morphology is changed could be identified.

- Discharge of wastewater (sewage and effluent) should be banned and should be allowed only after proper treatment.

- On both side of the riverbank, plantation of vegetation, trees, grasses which highly prevent the bank from the erosion activity.

- Made up the gabions, riprap along the river bank where erosion rate is higher.

- The mining of the raw material from the instream and floodplain area is done in a sustainable way.

- For preventing the river from upstream and downstream progressive degradation due to the construction of the dam's project should include regular analysis of river aspects along the main river and its tributaries. 


\section{Acknowledgments}

One of the authors (Vishal Kamboj) is highly grateful to the Department of Science and Technology (DST), New Delhi for financial Support through INSPIRE Fellowship (IF160805) and also grateful to the Department of Zoology and Environmental Science, Gurukula Kangri Vishwavidyalaya, Haridwar for providing the lab facility.

\section{Conflict of interest}

There is no conflict of interest.

\section{References}

Alexander, D.E. and Fairbridge, R.W. (1999). Encyclopedia of Environmental Science. Springer Science and Business Media. Angelier, E. (2003). Ecology of Streams and Rivers. Science Publishers, Inc., Enfield. pp. 215.

Castree, N. (2006). Questioning geography: fundamental debates. Wiley-Blackwell. pp. 84-85.

FAO (1998). Rehabilitation of rivers for fish, food, and agriculture. United Nations Organization, pp. 260.

Galay, V.J. (1983). Causes of river bed degradation. Water Resources Research, 19(5): 1057-1090. https://doi.org/10.1029/ WR019i005p01057.

Gibling, M.R. (2005). Discontinuity-bounded alluvial sequences of the southern gangetic plains, india: aggradation and degradation in response to monsoonal strength. Journal of Sedimentary Research, 75(3): 369-385. https://doi.org/10.2110/ jsr.2005.029

Hansen, K. (2000). Construction of a stair-stepped soil-cement bank protection. Denver, Colorado: American Society of Civil Engineers.

Hawkes, H.A. (1975). River zonation and classification. River ecology. Blackwell. pp. 312-374.

Holste, N. (2013). Riverbank Protection. Retrieved October 8, 2013.

Illies, J. and Botosaneanu, L. (1963). Problems and methods for the classification and ecological zoning of these currents, considering the faunistic point of view. Mitteilungen - Internationale Vereinigung fuer Theoretische und Angewandte Limnologie., 12: 1-57.

ISRD (International Scale of River Difficulty) (2015). Safety Code of American Whitewater. American Whitewater.

Kamboj, N. (2012). Some vegetative methods as a nature's tool for controlling soil erosion leading to floods. Biodiversity Conservation and Environment Management, Biotech books, pp. 191-198.

Kamboj, N. (2013). Soil erosion: a serious threat to degrade the land resources and its management. Environment Management, Daya publication, 161-165.

Kamboj, N. and Kamboj, V. (2019). Riverbed mining as a threat to in-stream agricultural floodplain and biodiversity of Ganges River, India. In: Kumar, V., Kumar, R., Singh, J. and Kumar, P. (eds) Contaminants in Agriculture and Environment: Health Risks and Remediation, Volume 1, Agro Environ Media, Haridwar, India, pp. 250-263, https:// doi.org/10.26832/ AESA-2019-CAE-0151-019

Kamboj, N. and Kamboj, V. (2019). Water quality assessment using overall index of pollution in riverbed-mining area of Ganga-River Haridwar, India. Water Science, 33 (1): 65-74, https://doi.org/10.1080/11104929.2019.1626631.

Kamboj, N., Bharti, M., Kamboj, V., Rani, A. and Sharma, S. (2016). A comparative study of physico-chemical and bacteriological parameters of three different ritual bathing ghats of Ganga River in India. ESSENCE: International Journal for Environmental Rehabilitation and Conservation, 7(2): 46-52.

Kamboj, V., Kamboj, N. and Sharma, S. (2017). Environmental impact of riverbed mining-a review. International Journal of 
Scientific Research and Reviews, 7(1): 504-520.

Kondolf, G.M. (1997). Hungry water: Effects of dams and gravel mining on river channels. Environmental Management, $21: 533$ -551 .

Kumar, V., Kumar, S., Srivastava, S., Singh, J., \& Kumar, P. (2018). Water quality of River Ganga with reference to physico-chemical and microbiological characteristics during Kanwar Mela 2017 at Haridwar, India: A case study. Archives of Agriculture and Environmental Science, 3(1): 58-63. https://doi.org/10.26832/24566632.2018.030108.

Leopold, L.B., Wolman, M.G. and Miller, J.P. (1964). Fluvial processes in geomorphology. San Francisco, W.H. Freeman and Co. pp. 522.

Miall, A.D. (1985). Architectural-element analysis: A new method of facies analysis applied to fluvial deposits. Earth Science Reviews, 22: 261-308.

Nanson, G.C. and Knighton, A.D. (1996). Anabranching rivers: their cause, character and classification. Earth Surface Processes and Landforms, 21(3):217-239. https://doi.org/10.1002/(SICI)1096837(199603)21:3\%3C217::AIDSP611\%3E3.0.CO;2-U.

Padmalal, D. and Maya, K. (2014). Sand mining. environmental impacts and selected case studies. Environmental Science and Engineering, 1-161. https://doi.org/10.1007/978-94-017-9144-1.

Warner, R.F. (1991). Impacts of environmental degradation on rivers, with some examples from the Hawkesbury-Nepean system. Australian Geographer, 22(1): 1-13. https://doi.org/10.1080/00049189108703016

Schumm, S. and Kahn, H. (1972). Experimental study of channel patterns. Bulletin of the Geological Society of America, 83(6): 1755-1770. https://doi.org/10.1130/0016-7606(1972)83.

Tarboton, D.G., Bras, R.L. and Rodriguez-Iturbe, I. (1991). On the extraction of channel networks from digital elevation data. Hydrological Processes, 5: 81-100.

Walbridge, C. and Singleton, M. (2005). Safety Code of American Whitewater. American Whitewater.

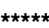

Cite this chapter as: Kamboj, V., Kamboj, N. and Sharma, A.K. (2020). A review on general characteristics, classification and degradation of river systems. In: Environmental Degradation: Causes and Remediation Strategies, Volume 1, Eds. Kumar, V., Singh, J. and Kumar, P., pp. 47-62, https://doi.org/10.26832/aesa-2020-edcrs-04 